\title{
A fekete- és fehérnyáras ligeterdők kapcsolata a Szigetközben
}

\author{
KEVEY Balázs \\ Pécsi Tudományegyetem, Ökológiai Tanszék, 7624 Pécs, Ifjúság u. 6.; \\ keveyb@gamma.ttk.pte.hu \\ Elfogadva: 2016. június 13.
}

Kulcsszavak: fehér nyár, fekete nyár, Magyar Alföld, szüntaxonómia, tájvédelmi körzet.

Összefoglalás: A Duna-medencei ártéri ligeterdők szüntaxonómiai kapcsolatai többször is vita tárgyát képezték szakmai körökben. A legutóbb javasolt osztályozás alátámasztására 65, az északnyugat-magyarországi Szigetköz feketenyáras és fehérnyáras ligeterdeiben (Carduo crispi-Populetum nigrae, Senecioni sarracenici-Populetum albae) gyüjtött felvételt elemeztem. A fiziognómiai eltérésekkel, a karakterfajok arányával, valamint a sokváltozós módszerekkel (cluster és főkoordináta elemzés) sikerült kimutatni a feketenyár ligetek átmeneti jellegű csoportját, amely azt bizonyítja, hogy a két asszociáció szukcessziós kapcsolatban van egymással.

\section{Bevezetés}

Magyarország északnyugati részének ártéri tája a Szigetköz, ahol a Duna kialakította legnagyobb és legváltozatosabb szigetvilágunkat. E tájon mintegy két és fél évtizeden át rendszeresen kutattam. Megfigyeléseim során igyekeztem kiválasztani azokat az erdőrészeket, amelyek - a számos emberi degradáló hatás ellenére - megőrizték természetszerü mivoltukat. Ilyen helyeken a fás társulásokból mintegy 1500 cönológiai felvételt készítettem. E felvételek és a tereptapasztalatok felhasználásával igyekeztem rekonstruálni a természetes szukcesszió egyes lépéseit és megszerkeszteni a Szigetköz erdeinek szukcessziós sémáját (lásd KEVEY 1993, 1998, 2008). Ezek szerint a lassú vízmozgás melletti, iszapos partszakaszokon mocsári (Phragmition és Magnocarition csoportok) és iszapnövényzet (Nanocyperion flavescentis csoport) jelenik meg. E társulások becserjésedésével jön létre a mandulalevelü bokorfüzes (Polygono hydropiperi-Salicetum triandrae), amely mintegy két évtized alatt fehérfüz ligetté (Leucojo aestivi-Salicetum albae) képes fejlődni. Az erős vízmozgású helyeken a folyami hordalékot kavics képezi (1. ábra). A kavicszátonyokon és a kavicsos partszakaszokon ruderális jellegű ártéri növényzet (Bidention tripartiti, Chenopodion fluviatile, Agropyro-Rumicion crispi csoportok asszociációi) jelenik meg. E társulások becserjésedésével jön lét- 
re a csigolya bokorfüzes (Rumici crispi-Salicetum purpureae), amely a termőhely további feltöltődésével, mintegy két évtized alatt feketenyár ligetekké (Carduo crispi-Populetum nigrae) fejlődik (2. ábra). A szukcesszió eddig leírt folyamatát mintegy 25 év alatt személyesen végig tudtam követni. A két puhafás ligeterdő (Leucojo aestivi-Salicetum albae, Carduo crispi-Populetum nigrae) termőhelyeinek további feltöltődésével a szukcesszió két ága piramisszerüen összezárul, s mindkét szálerdő fehérnyár ligetté (Senecioni sarracenici-Populetum albae) fejlődik (3. ábra). Ez utóbbi folyamat megfigyeléséhez és részletes tanulmányozásához azonban egy emberöltő kevés, hisz becslés szerint legalább 200 évig is eltarthat. A szigetközi fehérfüz és fehérnyár ligetek kapcsolatáról nemrég írtam egy cikket (KEVEY 2016). Jelen tanulmányban olyan megfigyeléseimet és felméréseimet szeretném megvitatni, amelyek alátámasztják azt a szukcessziós folyamatot, amelynek során a feketenyár ligetek fehérnyár ligetekké alakulnak.

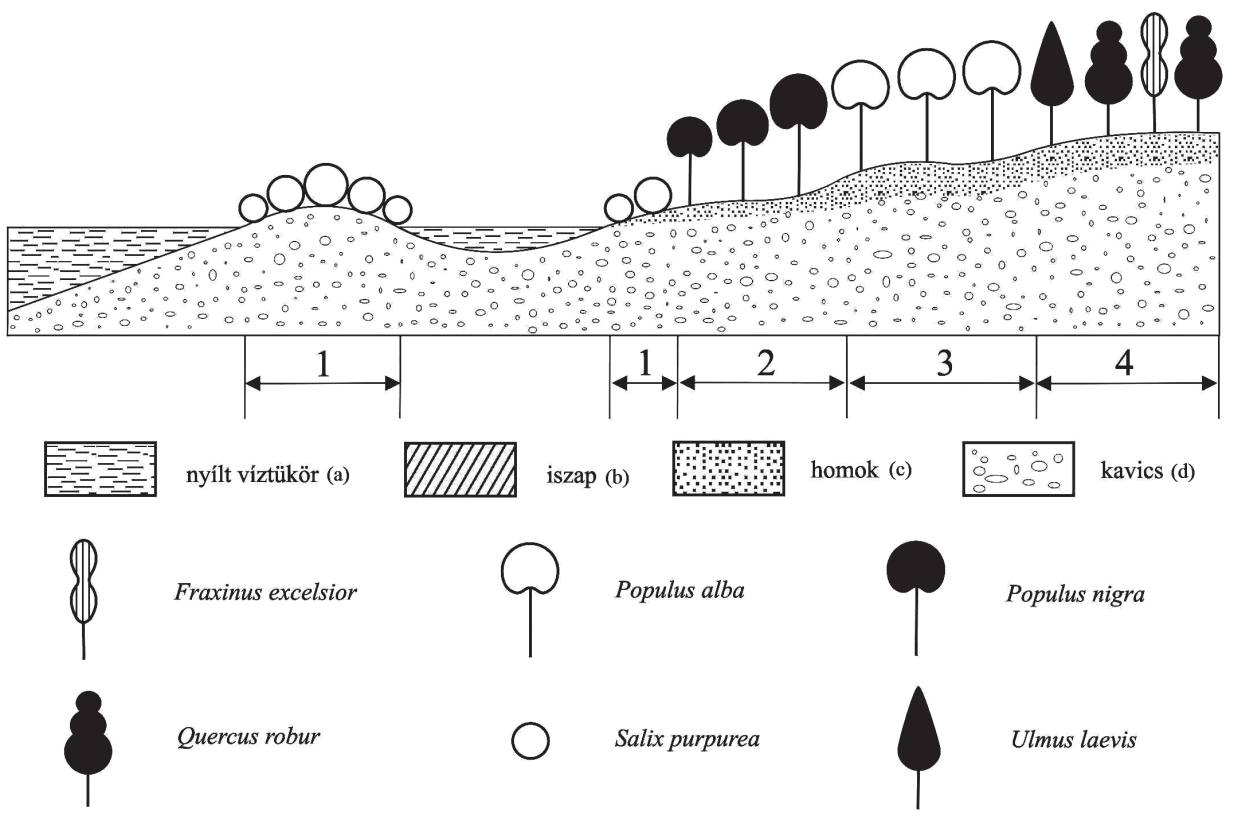

1. ábra. Vegetáció-keresztmetszet: Rajka „Tilos-erdő”. 1: csigolya bokorfüzes (Rumici crispi-Salicetum purpureae); 2: feketenyár liget (Carduo crispi-Populetum nigrae); 3: fehérnyár liget (Senecioni sarracenici-Populetum albae); 4: tölgy-kőris-szil liget (Pimpinello majoris-Ulmetum).

Fig. 1. Vegetation profile of „Tilos-erdő” at Rajka. (a) open water; (b) mud; (c) sand; (d) gravel; 1: purple willow thicket (Rumici crispi-Salicetum purpureae); 2: black poplar gallery forest (Carduo crispi-Populetum nigrae); 3: white poplar gallery forest (Senecioni sarracenici-Populetum albae); 4: oak-ash-elm gallery forest (Pimpinello majoris-Ulmetum). 


\section{Anyag és módszer}

\section{Kutatási terület jellemzése}

A Szigetköz hullámterének terjedelmes nemes nyárasai között még ma is megtalálhatók a természetes szukcesszió emlékét őrző puhafás ligeterdők (Leucojo aestivi-Salicetum albae, Carduo crispi-Populetum nigrae, Senecioni sarraceniciPopuletum albae) kisebb-nagyobb állományai. Közülük legritkábbak a feketenyár ligetek (Carduo crispi-Populetum nigrae). Állományaik a csigolya bokorfüzesek (Rumici crispi-Salicetum purpureae) feltöltődése révén újra és újra keletkeznek. Vannak a Szigetközben olyan szigetek is (pl. Ásványráró „Laci-sziget” és „ÖregÁrva-sziget” közötti kisebb sziget), amelyek - fakitermelési céllal - szinte megközelíthetetlenek. Az ilyen szigeteken kialakult feketenyár ligetek még sohasem voltak letermelve, koruk így a 150-200 évet is elérheti. A területen tehát a legkülönbözőbb korú feketenyár ligetek is megtalálhatók, s összehasonlításukkal lehetőség nyílik a szukcessziós viszonyok tanulmányozására. A feketenyár ligetek feletti, 1-1,5 m-rel magasabb szintet már fehérnyár ligetek (Senecioni sarraceniciPopuletum albae) borítják. A két asszociáció a Szigetközben több helyen is érintkezik egymással (pl. Dunasziget „Vörös-füzes”, „Hajós-sziget”; Kisbodak „Pálfisziget”; Ásványráró „Madarász-sziget”).

\section{Alkalmazott módszerek}

A cönológiai felvételek a Zürich-Montpellier növénycönológiai iskola (BECKING 1957; BRAUN-BLANQUET 1964) hagyományos kvadrát-módszerével készültek. Tanulmányomban felhasználtam a korábbi monográfiámban (KEVEY 2008) közölt feketenyár ligetek (Carduo crispi-Populetum nigrae) és a fehérnyár ligetek (Senecioni sarracenici-Populetum albae) 25-25 felvételét. E felvételek mellett a vizsgálatba vontam még 15 eddig közöletlen feketenyár liget (Carduo crispiPopuletum nigrae) felvételt is, amelyek túlnyomó része már jobban feltöltődött ártéri szinten helyezkednek el. Megítélésem szerint ezek az idős állományok jelenthetnek némi átmenetet a feketenyáras és fehérnyáras ligeterdők között.

A felvételek táblázatos összeállítása, valamint a karakterfajok csoportrészesedésének és csoporttömegének kiszámítása az „NS” számítógépes programcsomaggal (Kevey és HirmanN 2002) történt. A felvételkészítés és a hagyományos statisztikai számítások - kissé módosított - módszerét korábban részletesen közöltem (KEVEY 2008). A SYN-TAX 2000 program (PoDANI 2001) segítségével bináris cluster-analízist (Method: Complete link; Coefficient: Baroni-Urbani et Buser) és ordinációt végeztem (Method: Principal coordinates analysis; Coefficient: Baroni-Urbani et Buser). E sokváltozós elemzések segítségével igyekeztem megállapítani, hogy a feketenyár ligetekben (Carduo crispi-Populetum nigrae) készült 


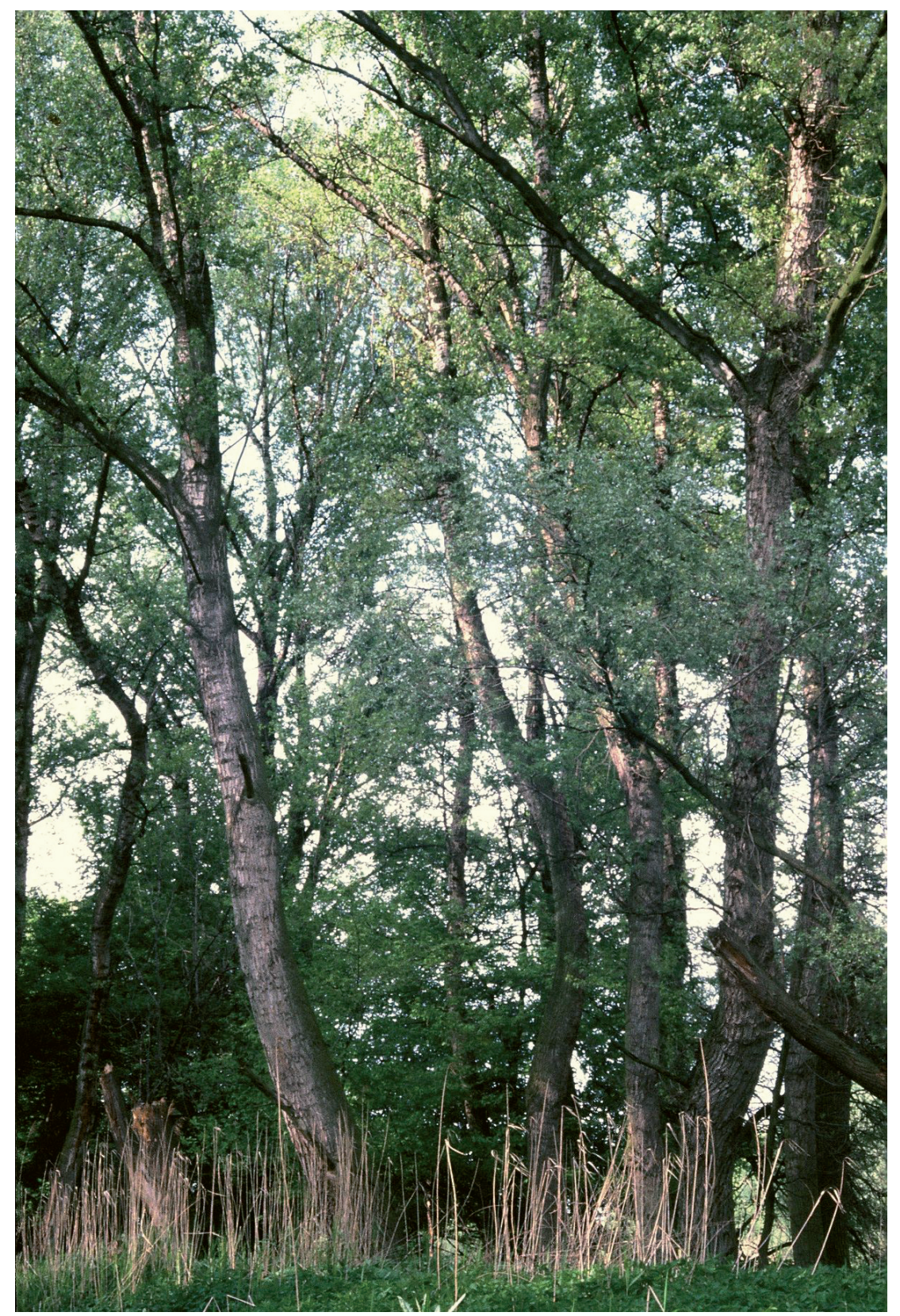

2. ábra. Feketenyár liget (Carduo crispi-Populetum nigrae) a Szigetközben: Ásványráró „Öreg-Árvasziget” és „Laci-sziget” közötti szigeten (Kevey Balázs felvétele).

Fig. 2. Black poplar gallery forest (Carduo crispi-Populetum nigrae) in the Szigetköz on an island between the islands „Öreg-Árva-sziget” and „Laci-sziget” (Photo by B. Kevey). 
Fekete- és fehérnyáras ligeterdők a Szigetközben

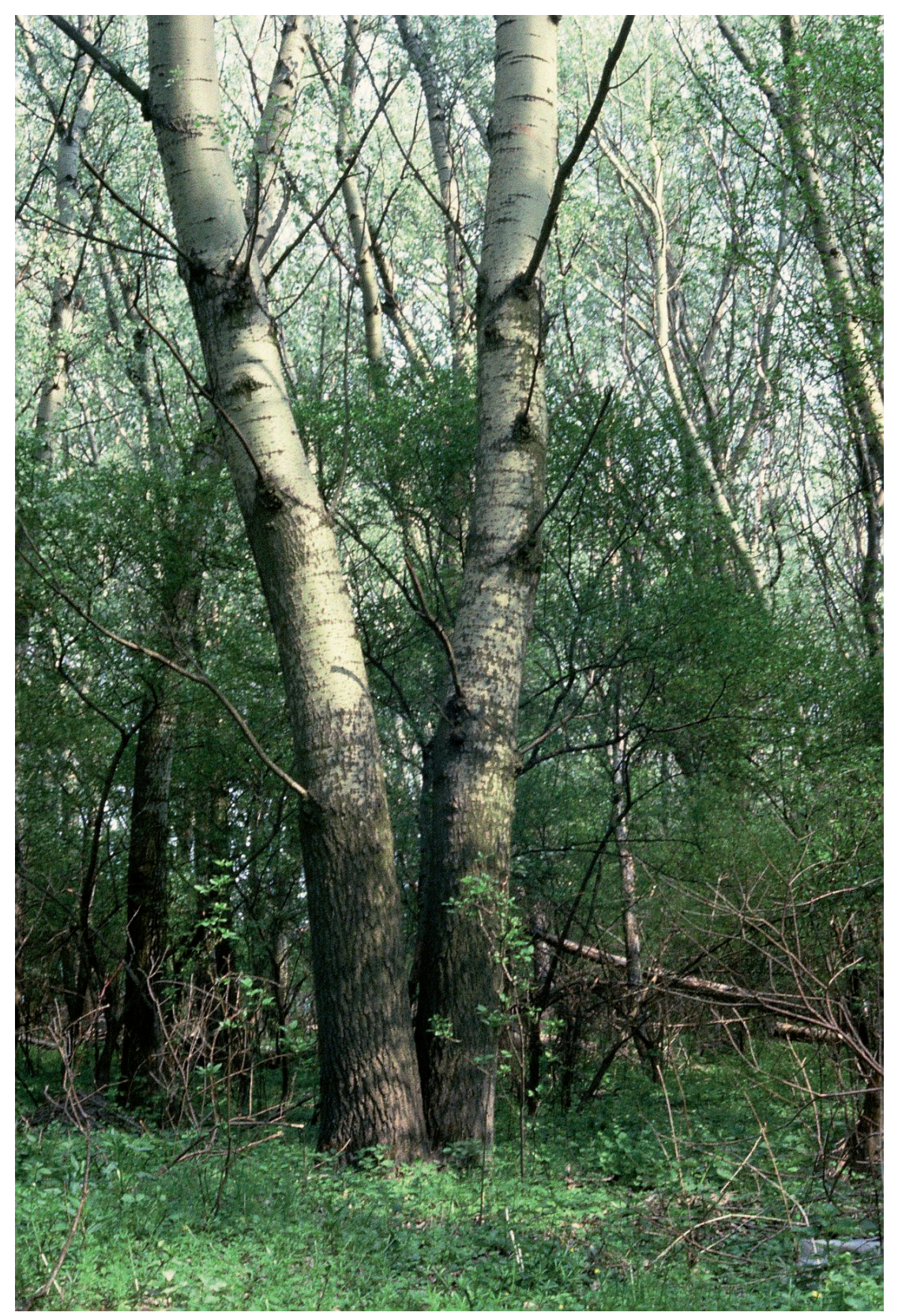

3. ábra. Fehérnyár liget (Senecioni sarracenici-Populetum albae) a Szigetközben: Dunakiliti „KülsőJegenyés" (Kevey Balázs felvétele).

Fig. 3. White poplar gallery forest (Senecioni sarracenici-Populetum albae) in the Szigetköz („KülsőJegenyés", Dunakiliti, photo by B. Kevey). 
40 felvétel (1-2. táblázat, elektronikus mellékletben) között melyek azok, amelyek átmenetet képeznek a fehérnyár ligetek (Senecioni sarracenici-Populetum albae) felé. A felvételeket (27 és 13 felv.) azután két külön táblázatban egyesítettem (3. táblázat, elektronikus mellékletben), majd mindkettőt a hagyományos statisztikai módszerekkel (csoportrészesedés, csoporttömeg) vizsgáltam tovább.

A fajok esetében KIRÁly (2009), a társulásoknál pedig BORHIDI és KEVEY (1996), KeVEY (2008), ill. BorHIDI et al. (2012), nómenklatúráját követem. A társulástani és a karakterfaj-statisztikai táblázatok felépítése az újabb eredményekkel (OBERDORFER 1992; MUCINA et al. 1993; BORHIDI et al. 2012; KEVEY 2008) módosított Soó (1980) féle cönológiai rendszerre épül. A növények cönoszisztematikai besorolásánál is elsősorban Soó (1964, 1966, 1968, 1970, 1973, 1980) Synopsis-ára támaszkodtam, de figyelembe vettem az újabb kutatási eredményeket is (vö. BORHIDI 1993, 1995; HoRVÁth et al. 1995).

\section{Eredmények}

Sokváltozós statisztikai elemzések eredményei

A sokváltozós elemzések azt mutatták, hogy a feketenyár ligetek (Carduo crispi-Populetum nigrae) felvételei között olyanok is vannak, amelyek átmenetet képeznek a fehérnyár ligetek felé (Senecioni sarracenici-Populetum albae). A dendrogramon (4. ábra) és az ordinációs diagramon (6. ábra) ugyanis látszik, hogy a két asszociáció nem különül el egymástól élesen. Ezen ábrák alapján $13 \mathrm{db}$. átmeneti jellegü feketenyár liget felvételt kivettem a további elemzésből. Az újra elvégzett elemzés után a dendrogramon (5. ábra) és az ordinációs diagramon (7. ábra) a két erdőtársulás már szépen elkülönült. A feketenyár ligetek felvételei így két csoportba kerültek: tipikusnak tartott felvételek (27 felv.) és átmeneti jellegü felvételek (13 felv.). E két csoportot ezután külön-külön vizsgáltam.

\section{Fiziognómia}

A két ligeterdő társulás között némi fiziognómiai különbségek mutatkoznak. Ezek közül leginkább szembetűnő az, hogy amíg a fehérnyár ligetek (Senecioni sarracenici-Populetum albae) lombkoronájában a Populus alba, igen ritkán az Alnus incana uralkodik, addig a feketenyár ligetek (Carduo crispiPopuletum nigrae) legfelső szintjében elsősorban a Populus nigra, vagy ritkábban a Salix alba képez állományt.

A cserjeszint borítottságában is jelentkezik különbség. A magasabban fekvő fehérnyár ligetek cserjeszintje igen fejlett, átlagosan $52,2 \%$ borítást mutat. A mintegy 1-1,5 m-rel mélyebben fekvő feketenyár ligetek (27 felv.) cserjeszintje viszont sokkal fejletlenebb, átlagos borítása mindössze 12,9\%. Az átmeneti jellegü 


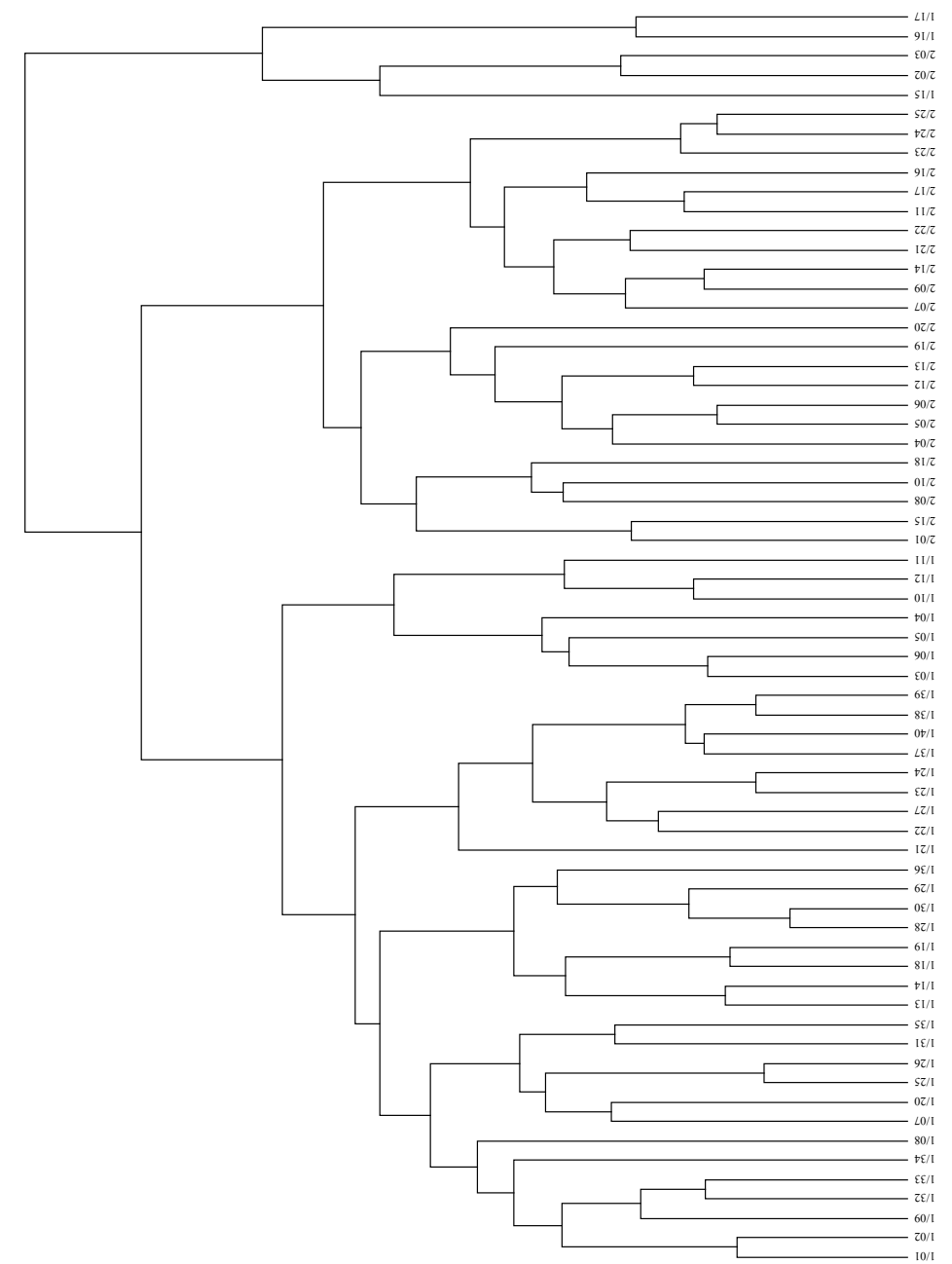

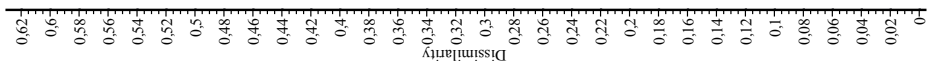

4. ábra. Feketenyár és fehérnyár ligetek bináris dendrogramja I. (Teljes lánc módszer, Baroni-Urbani et Buser kofficiens); 1/1-40: Carduo crispi-Populetum nigrae, Szigetköz (Kevey 2008: 25 felv.; Kevey ined.: 15 felv.); 2/1-25: Senecioni sarracenici-Populetum albae, Szigetköz (Kevey 2008: 25 felv.).

Fig. 4. Binary dendrogram of black- and white poplar gallery forests I. (Method: Complete link; Coefficient: Baroni-Urbani et Buser); 1/1-40: Carduo crispi-Populetum nigrae, Szigetköz (KeveY 2008: 25 relevés.; KeveY ined.: 15 relevés); 2/1-25: Senecioni sarracenici-Populetum albae, Szigetköz (KeVEy 2008: 25 relevés). 


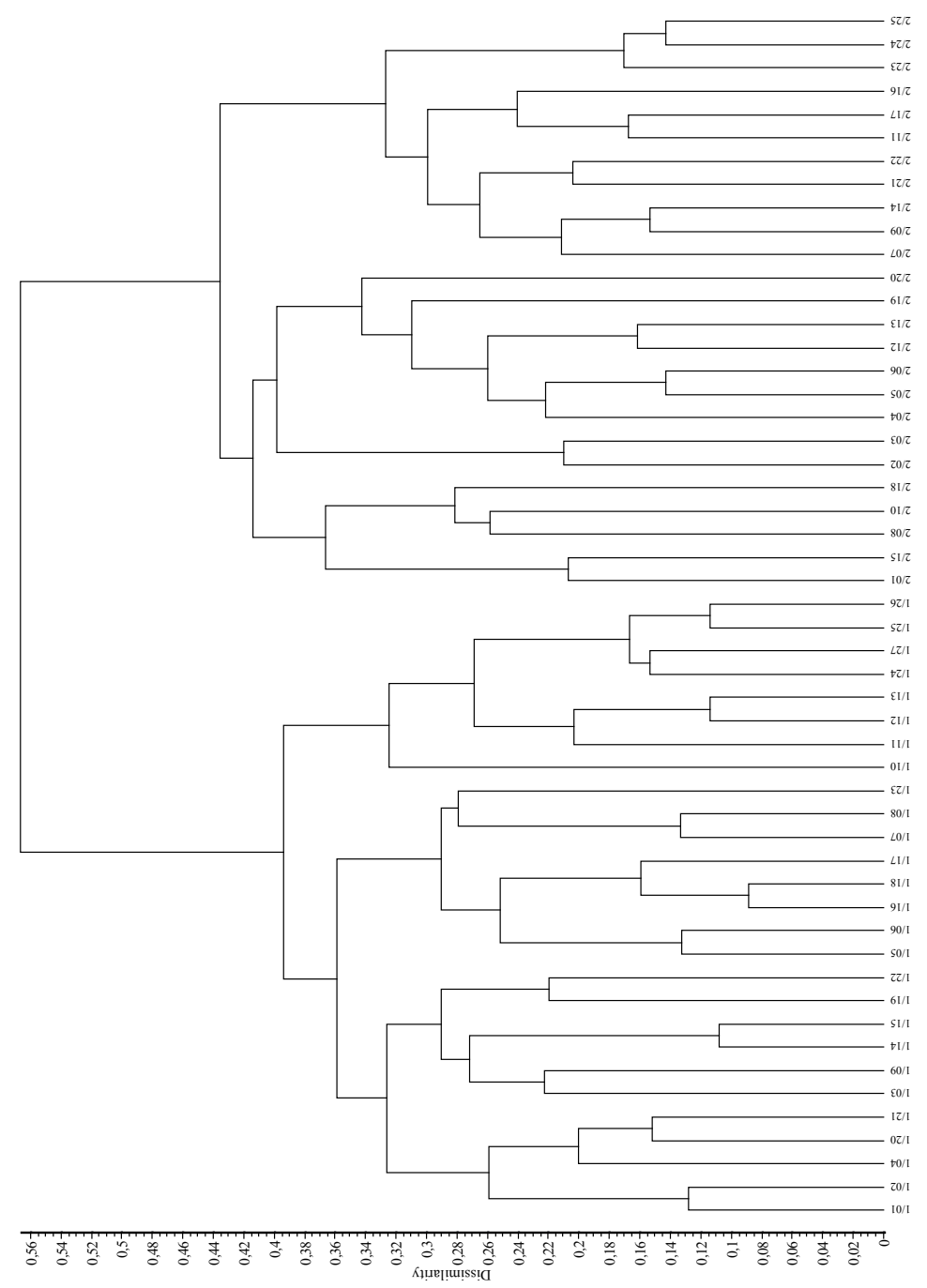

5. ábra. Feketenyár és fehérnyár ligetek bináris dendrogramja II. (Teljes lánc módszer, BaroniUrbani et Buser kofficiens). 1/1-27: Carduo crispi-Populetum nigrae, Szigetköz (Kevey 2008: 24 felv.; Kever ined.: 3 felv.) 2/1-25: Senecioni sarracenici-Populetum albae, Szigetköz (Kevey 2008: 25 felv.).

Fig. 5. Binary dendrogram of black- and white poplar gallery forests II. (Method: Complete link; Coefficient: Baroni-Urbani et Buser); 1/1-27: Carduo crispi-Populetum nigrae, Szigetköz (Kevey 2008: 24 relevés; KeVEY ined.: 3 relevés); 2/1-25: Senecioni sarracenici-Populetum albae, Szigetköz

(KeVEy 2008: 25 relevés). 
feketenyár ligetek (13 felv.) cserjeszintjének átlagos borítottsága ezzel szemben 33,1\%-nak bizonyult (8. ábra).

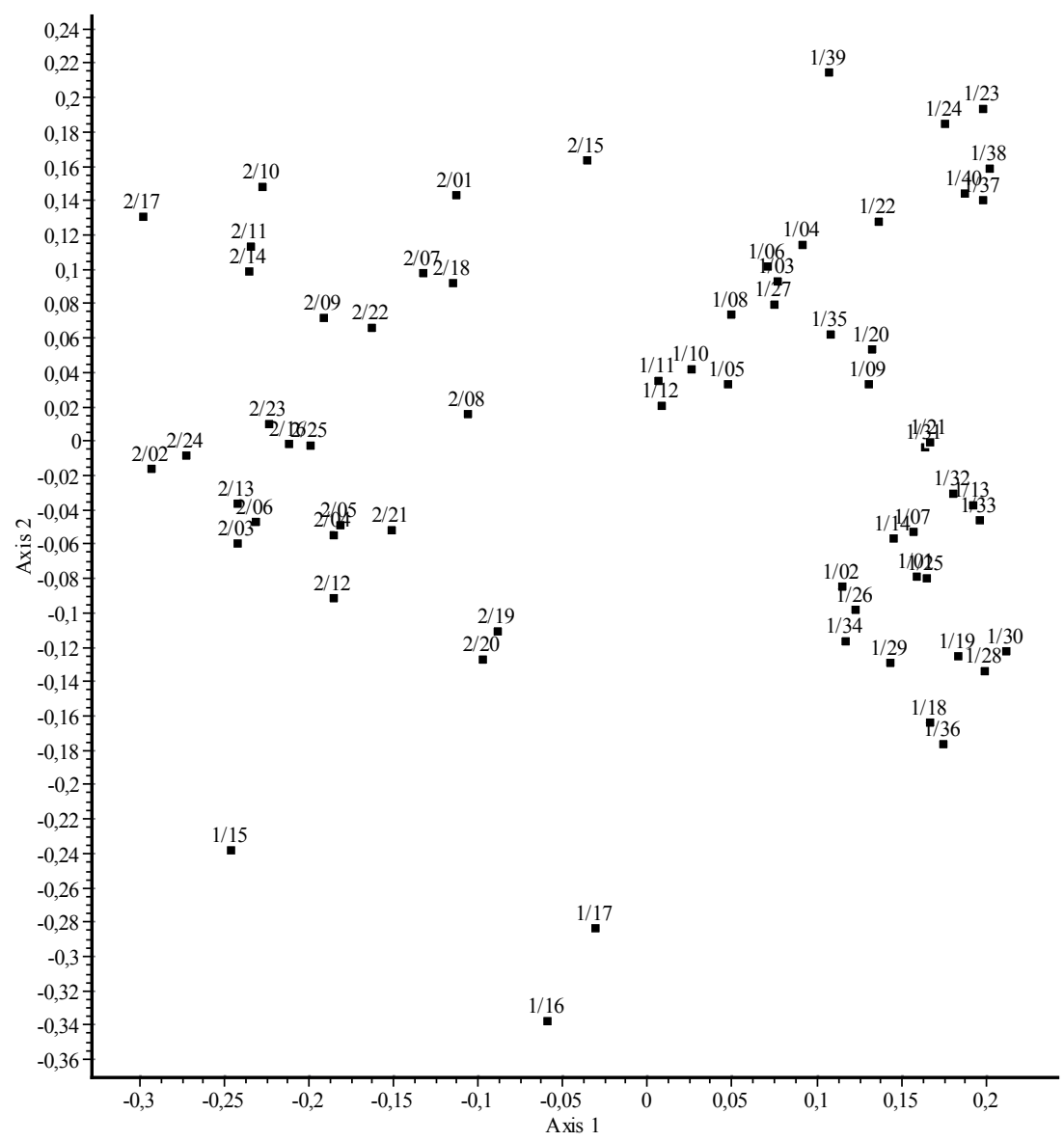

6. ábra. Feketenyár és fehérnyár ligetek bináris ordinációs diagramja I. (Főkoordináta analízis, Baroni-Urbani et Buser kofficiens); 1/1-40: Carduo crispi-Populetum nigrae, Szigetköz (KEvEY 2008: 25 felv.; KEVEY ined.: 15 felv.); 2/1-25: Senecioni sarracenici-Populetum albae, Szigetköz (KEVEY 2008: 25 felv.).

Fig. 6. Binary ordination diagram of black- and white poplar gallery forests I. (Method: Principal coordinates analysis; Coefficient: Baroni-Urbani et Buser); 1/1-40: Carduo crispi-Populetum nigrae, Szigetköz (Kevey 2008: 25 relevés; Kevey ined.: 15 relevés); 2/1-25: Senecioni sarracenici-Populetum albae, Szigetköz (KEVEY 2008: 25 relevés). 
A gyepszint fáciesképző fajai terén is mutatkozik némi különbség. Amíg a fehérnyár ligetekben az Impatiens noli-tangere, a Glechoma hederacea, a Lamium maculatum és a Ranunculus ficaria is lehet fáciesképző, addig a feketenyár ligetek általában vegyes típusúak, igen ritkán a Phalaris arundinacea képezhet fáciest. $\mathrm{Az}$ átmeneti jellegű feketenyár ligetekben azonban olykor előfordul a Glechoma hederacea fácies.

\section{Karakterfajok aránya}

Megvizsgáltam a karakterfajok arányát a tipikusnak tartott (27 felv.) és az átmenetijellegűnek tartott (13 felv.) feketenyár ligetekben (Carduocrispi-Populetum nigrae), valamint a fehérnyár ligetekben (Senecioni sarracenici-Populetum albae).

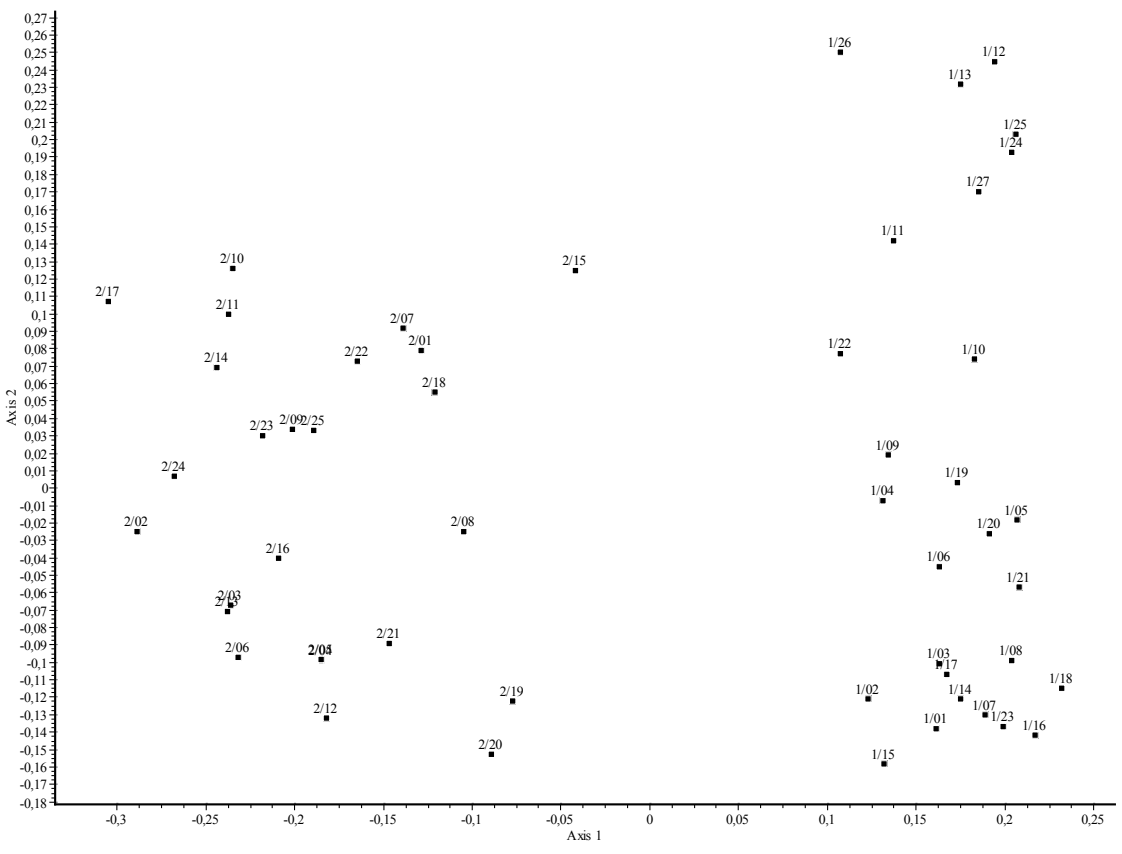

7. ábra. Feketenyár és fehérnyár ligetek bináris ordinációs diagramja II. (Főkoordináta analízis, Baroni-Urbani et Buser kofficiens); 1/1-27: Carduo crispi-Populetum nigrae, Szigetköz (KEVEY 2008: 24 felv.; Kever ined.: 3 felv.); 2/1-25: Senecioni sarracenici-Populetum albae, Szigetköz (KEVEY 2008: 25 felv.).

Fig. 7. Binary ordination diagram of black and white poplar gallery forests II. (Method: Principal coordinates analysis; Coefficient: Baroni-Urbani et Buser); 1/1-27: Carduo crispi-Populetum nigrae, Szigetköz (Kevey 2008: 24 relevés; Kevey ined.: 3 relevés); 2/1-25: Senecioni sarracenici-Populetum albae, Szigetköz (KEVEY 2008: 25 relevés). 
Különösen a csoportrészesedési adatok szolgáltattak használható eredményeket, amelyek jelzik a két asszociáció közötti átmenetet is (9-15. ábra, 4. táblázat, elektronikus mellékletben). Így csökkenő tendenciát mutat a Phragmitetea s. 1., a Molinio-Juncetea s. 1., a Bidentetalia s. l. és a Salicetalia purpurae elemek aránya (9-12. ábra, míg növekvő tendenciát észlelhető a Querco-Fagetea, a Fagetalia és a Quercetea pubescentis-petraeae elemek terén (13-15. ábra).

\section{Megvitatás}

A feketenyár ligetek (Carduo crispi-Populetum nigrae) és a fehérnyár ligetek (Senecioni sarracenici-Populetum albae) leírását, a szukcesszióban elfoglalt helyüket korábban már leírtam (KEVEY 1998, 2008). Alább azon információkat szeretném kiemelni, amelyek valószínűsítik e két asszociáció közötti szukcessziós kapcsolatot. A választ elsősorban az átmeneti jellegű feketenyár felvételek elemzési eredményeitől várhatjuk.

A feketenyár ligetek cserjeszintje általában gyengén fejlett, a fehérnyár ligeteknél pedig erősen fejlett. Az átmeneti jellegü felvételeknél e téren köztes eredmény született (lásd. 2. táblázat, elektronikus mellékletben; 8. ábra), amely jól mutatja a két asszociáció közötti átmenetet.

A karakterfajok arányát tekintve is gyakran kaptam köztes eredményeket. Az erősen higrofil szüntaxonok esetében, mint a Phragmitetea s. 1. (9. ábra), a Molinio-Juncetea s. 1. (10. ábra), a Bidentetalia s. 1. (11. ábra) és a Salicetalia purpureae (12. ábra), csökkenő tendenciát tapasztalunk. Ilyen csökkenés tapasztalható egyes nedvesség kedvelö fajok K-értékeinél: Bidens tripartita, Cardamine pratensis, Carex acuta, Galium palustre, Myosotis nemorosa, Persicaria hydropiper, Rorippa amphibia, Solanum dulcamara, Stachys palustris. Ez érthetö is, hisz a mélyebben fekvő feketenyár ligetek több elárasztásban részesülnek, mint a magasabban fekvő fehérnyár ligetek. A mezofil és xerofil jellegű szüntaxonok esetében fordított a helyzet, így a Querco-Fagetea (13. ábra), a Fagetalia (14. ábra) és a Quercetea pubescentis-petraeae (15. ábra) jellegủ elemek már a kevésbé nedves fehérnyár ligetek felé mutatnak növekvő arányt (4. táblázat, elektronikus mellékletben). Ilyen emelkedés tapasztalható egyes mezofil jellegü fajoknál: Alnus incana, Euonymus europaeus, Circaea lutetiana, Lapsana communis, Populus alba, Quercus robur (3. táblázat, elektronikus mellékletben).

Fenti átmeneti jellegủ felvételek nagy valószínüséggel bizonyítják, hogy a feketenyár és a fehérnyár ligetek között szukcessziós kapcsolat áll fenn. Elvileg e felvételeket a két asszociáció közötti szukcesszió sor különböző pontjain lehetne elhelyezni. Nagyobb részük a feketenyár ligetekhez áll közelebb, de néhány felvétel (elsősorban Kisbodak „Pálfi-erdő”) már igen közel áll a fehérnyár ligetekhez. 


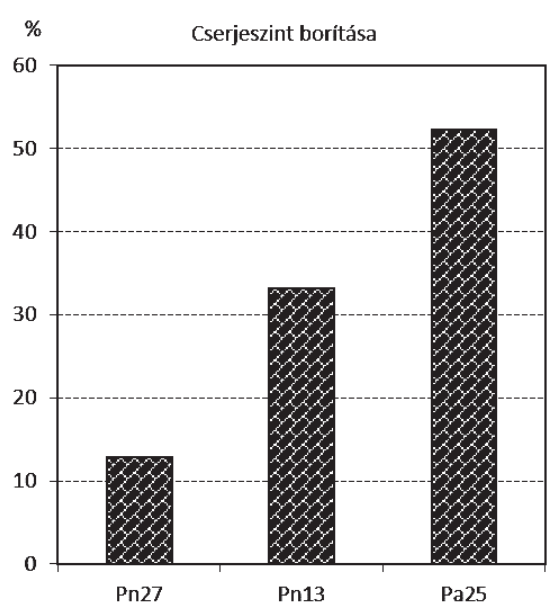

8. ábra. Feketenyár és fehérnyár ligetek cserjeszintjének borítása. Rövidítések lábjegyzetben* Fig. 8. Shrub layer ground cover in the blackand white poplar gallery forests.*.

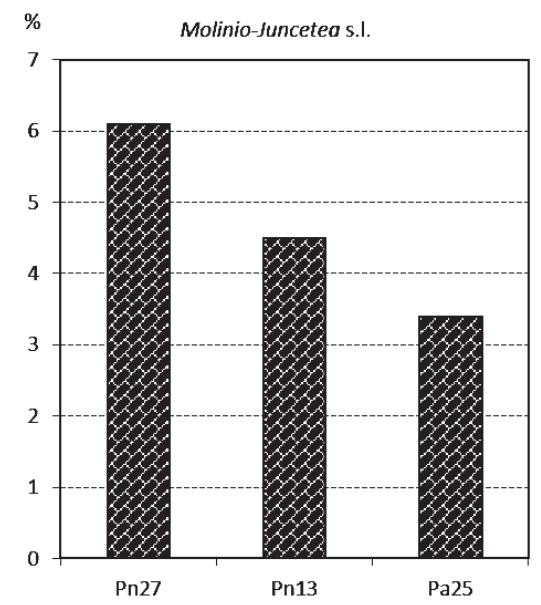

10. ábra. Molinio-Juncetea s. 1. fajok aránya. Rövidítések a 8. ábra szerint.

Fig. 10. Proportion of Molinio-Juncetea s. 1. species. For abbreviations see Figure 8.

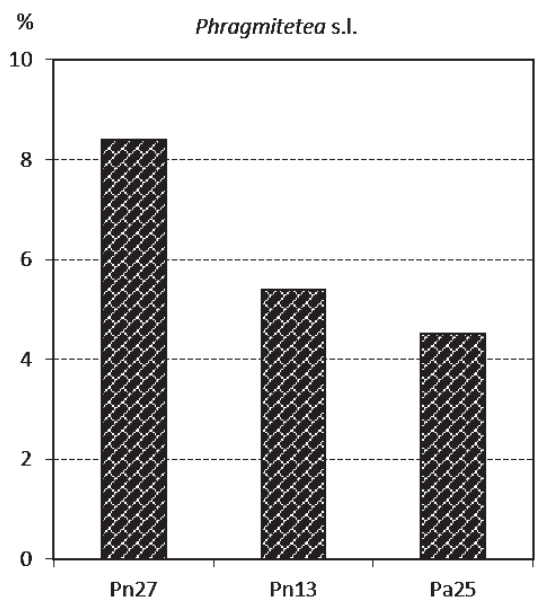

9. ábra. Phragmitetea s. l. fajok aránya. Rövidítések a 8. ábra szerint.

Fig. 9. Proportion of Phragmitetea s. 1. species. For abbreviations see Figure 8.

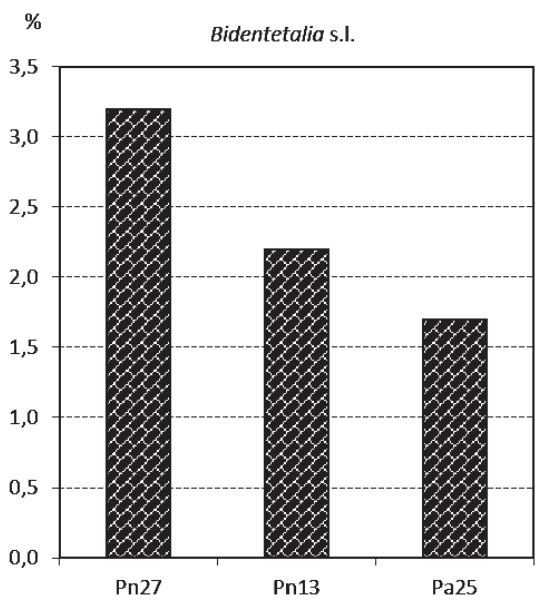

11. ábra. Bidentetalia s. 1. fajok aránya. Rövidítések a 8. ábra szerint.

Fig. 11. Proportion of Bidentetalia s. 1. species. For abbreviations see Figure 8.

* Pn27: Carduo crispi-Populetum nigrae tipikus állományai, Szigetköz (Kevey 2008: 24 felv.; Kevey ined. 3 felv.); Pn13: Carduo crispi-Populetum nigrae átmeneti állományai, Szigetköz (Kevey 2008: 1 felv.; Kevey ined. 12 felv.); Pa25: Senecioni sarracenici-Populetum albae, Szigetköz (KEVEy 2008: 25 felv.). Pn27: typical stands of Carduo crispi-Populetum nigrae, Szigetköz (Kevey 2008: 24 relevés; Kevey ined. 3 relevés); Pn13: intermediate stands of Carduo crispi-Populetum nigrae, Szigetköz (KeVEy 2008: 1 relevés; Kevey ined. 12 relevés); Pa25: Senecioni sarracenici-Populetum albae, Szigetköz (Kevey 2008: 25 relevés). 


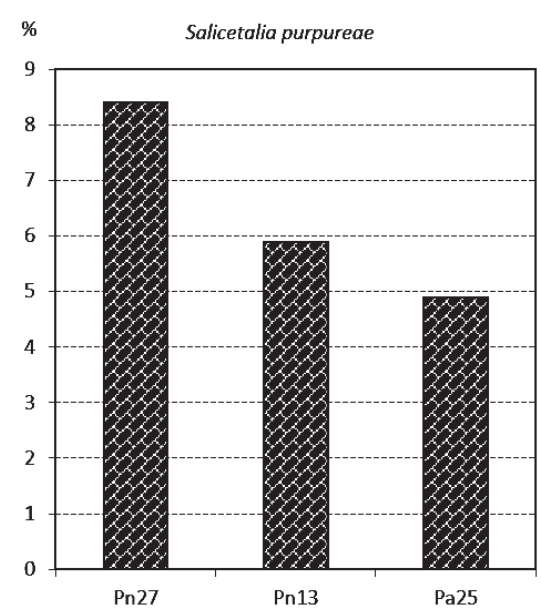

12. ábra. Salicetalia purpureae fajok aránya. Rövidítések a 8. ábra szerint.

Fig. 12. Proportion of Salicetalia purpureae species. For abbreviations see Figure 8.

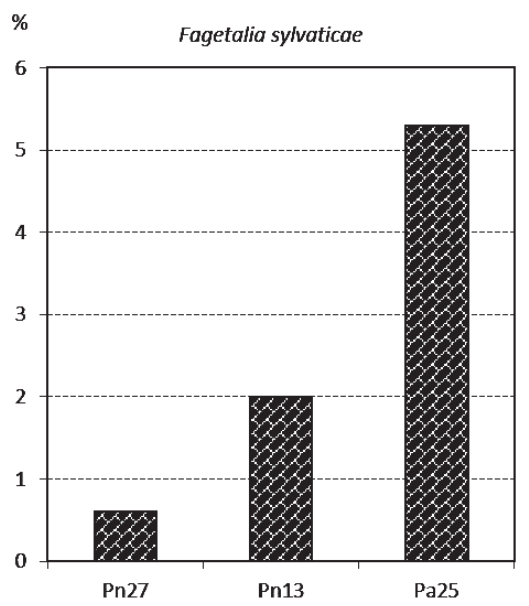

14. ábra. Fagetalia fajok aránya. Rövidítések a 8. ábra szerint.

Fig. 14. Proportion of Fagetalia species. For abbreviations see Figure 8 .

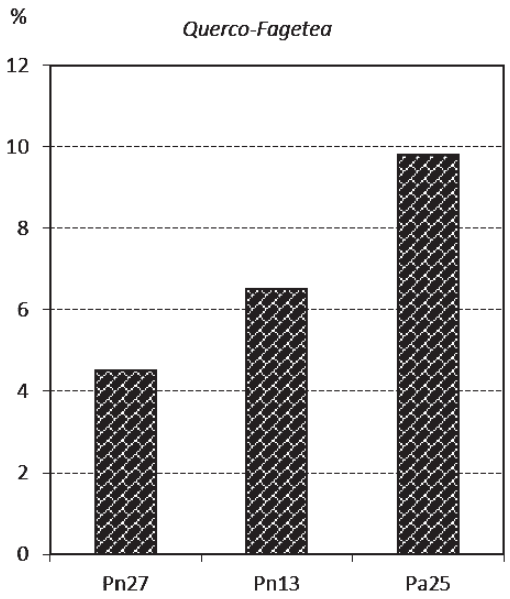

13. ábra. Querco-Fagetea fajok aránya. Rövidítések a 8. ábra szerint.

Fig. 13. Proportion of Querco-Fagetea species. For abbreviations see Figure 8.

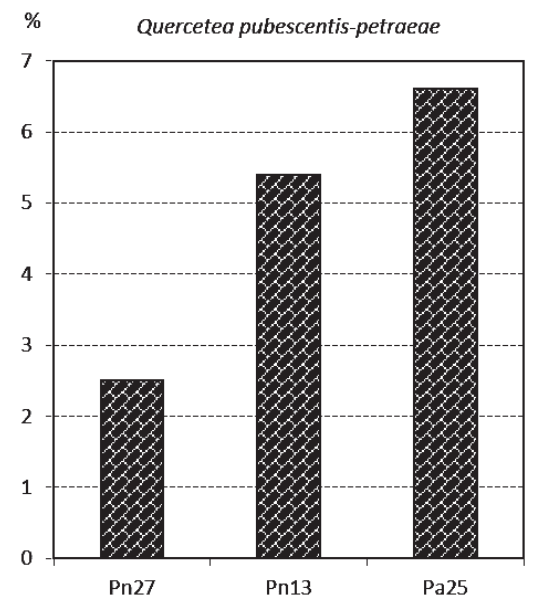

15. ábra. Quercetea pubescentis-petraeae fajok aránya. Rövidítések a 8. ábra szerint.

Fig. 15. Proportion of Quercetea pubescentispetraeae species. For abbreviations see Figure 8.

A két asszociáció közötti szukcessziós átmenetet egy emberöltő alatt nem lehet végigkísérni. Az egyes lépésekre azonban az asszociációk egymás mellettiségéből, az ártéri szintek magasságából, valamint a fent jelzett fiziognómiai és szüntaxonómiai átmenetekből következtethetünk. E folyamat az alábbi mó- 
don játszódhat le. Az idősödő feketenyáras ligetek már nem tudnak megújulni, aljnövényzetükben csak elvétve találhatunk Salix alba és Populus nigra csíranövényeket, csemetéket. Ennek több oka is lehet. Egyrészt e fafajok magja csak akkor képes kicsírázni, ha friss öntésiszapra vagy homokra kerül. Másrészt e feketenyáras ligeterdők gyepszintjében a lágyszárúak konkurenciája gátolhatja a Salix alba és a Populus nigra magjainak csírázását és a csíranövények továbbfejlödését. Amennyiben az árhullám friss öntésiszapot terít az erdő gyepszintjére, az idős fák árnyékoló hatása akadályozhatja meg a csíranövények megerősödését. Végül e feketenyáras ligeterdők termőhelyét az árhullámok által lerakott hordalék évről-évre fokozatosan magasítja. Mire egy feketenyáras ligeterdő eléri az idős kort, a termőhely annyira magas lesz, hogy már alig alkalmas a Salix alba és a Populus nigra fiatal egyedeinek befogadására. Ha ilyen erdőkben nem folytatnának erdőgazdálkodást, hosszú távú monitorozással végig lehetne kísérni a feketenyár liget társulás fehérnyáras ligeterdővé történő átalakulását. Ez úgy kezdődhet, hogy a kiöregedett Salix alba és Populus nigra egyedek egy idő után összeroskadnak. A megmagasodott ártéri szint már nem kínál újabb lehetőséget a fiatal Salix alba és a Populus nigra magjainak csírázására. A Populus alba ezzel szemben a megváltozott termőhelyi viszonyok mellett a lékekben már jól csírázik. Mivel a megmagasodott ártéri szint már ritkábban kerül elárasztásra, ezért a Populus alba csíranövények további fejlődésének lehetősége biztosítva van. A folyamatosan összeroskadó idős Salix alba és Populus nigra egyedek helyét így fokozatosan fiatal Populus alba egyedek foglalják el, majd a feketenyáras ligetet a fehérnyáras ligeterdő váltja fel. E hipotézist alátámaszthatja az, hogy az idős, magasabb ártéri szinten levő feketenyár ligetekben szórványosan megtalálhatók a Populus alba csíranövényei és cserje termetủ egyedei, $s$ a lágyszárú szintben is felbukkanhatnak olyan növények, amelyek már a fehérnyáras ligetekre jellemzőek: pl. Arum orientale, Paris quadrifolia, Scilla vindobonensis, Stachys sylvatica stb. Ugyancsak a két asszociáció közötti szukcessziós kapcsolatot bizonyítja az, hogy sok fehérnyár ligetben megtalálhatók a Populus nigra igen idős példányai, amelyek feltehetően a korábbi szukcessziós stádiumból maradhattak vissza, azaz egykori feketenyár ligetek emlékét őrzik (pl. Budapest „Háros-sziget”; Dunasziget „Vörös-füzes”; Zákány „Sziget” stb.).

Mint ismeretes, mind a Populus nigra, mind pedig a Populus alba pionír jellegü fafaj. Érdekes összefüggések kerülhetnek felszínre annak vizsgálatával, hogy a szukcesszió során miként váltja fel a Populus nigra-t a Populus alba. Ez azonban már nem cönológiai, hanem autökológiai kérdés, amelynek eldöntéséhez hosszú távú monitorozásra lenne szükség, ahol kizárjuk az erdőgazdálkodás és a folyószabályozás zavaró hatását egyaránt. 
A fenti érvek szerint a feketenyár és fehérnyár ligetek között szukcessziós kapcsolat áll fenn. Szüntaxonómiai helyük az alábbi módon vázolható:

Divízió: Querco-Fagea Jakucs 1967

Osztály: Salicetea purpureae Moor 1958

Rend: Salicetalia purpureae Moor 1958

Csoport: Salicion albae Soó 1930 em. Th. Müller et Görs 1958

Alcsoport: Populenion nigro-albae Kevey 2008

Társulás: Carduo crispi-Populetum nigrae Kevey in Borhidi et Kevey 1996

Társulás: Senecioni sarracenici-Populetum albae Kevey in Borhidi et Kevey 1996

\section{Köszönetnyilvánítás}

Köszönetem illeti azon kollégákat, akik terepismeretükkel, kalauzolásukkal, vagy egyéb módon segítették munkámat: Alexay Zoltán, Belovitz Károly, Csiba László, Koltai Gábor, Toldi Miklós.

\section{Rövidítések}

A1: felső lombkoronaszint; A2: alsó lombkoronaszint; Agi: Alnenion glutinosae-incanae; Ai: Alnion incanae; Alo: Alopecurion pratensis; Aon: Alnion glutinosae; APa: Abieti-Piceea; AQ: Aceri tatarici-Quercion; AR: AgropyroRumicion crispi; Ar: Artemisietea; Ara: Arrhenatheretea; Arn: Arrhenatherion elatioris; Ate: Alnetea glutinosae; B1: cserjeszint; B2: újulat; Bec: Beckmannion eruciformis; Bia: Bidentetea; Bin: Bidention tripartiti; Bra: Brometalia erecti; C: gyepszint; Cal: Calystegion sepium; Cau: Caucalidion platycarpos; Cgr: Caricenion gracilis; Che: Chenopodietea; Chr: Chenopodion rubri; ChS: Chenopodio-Scleranthea; Cp: Carpinenion betuli; Cyc: Cynosurion cristati; CyF: Cynodonto-Festucenion; Des: Deschampsion caespitosae; Epa: Epilobietea angustifolii; ex litt.: ex litteris (írásbeli közlés); F: Fagetalia sylvaticae; FB: Festuco-Bromea; FBt: Festuco-Brometea; FiC: Filipendulo-Cirsion oleracei; FPe: Festuco-Puccinellietea; FPi: Festuco-Puccinellietalia; Fvg: Festucetea vaginatae; Fvl: Festucetalia valesiacae; GA: Galio-Alliarion; ined.: ineditum (kiadatlan közlés); LeP: Lemno-Potamea; Mag: Magnocaricetalia; Moa: Molinietalia coeruleae; MoA: Molinio-Arrhenatherea; MoJ: Molinio-Juncetea; Nc: Nanocyperion flavescentis; NC: Nardo-Callunetea; NG: Nasturtio-Glycerietalia; Ona: Onopordetalia; Pea: Potametea; Pla: Plantaginetea; Pna: Populenion 
nigro-albae; Pol: Polygonion avicularis; PP: Pulsatillo-Pinetea; Prf: Prunion fruticosae; Pru: Prunetalia spinosae; Pte: Phragmitetea; QFt: Querco-Fagetea; Qpp: Quercetea pubescentis-petraeae; Qr: Quercetalia roboris; Qrp: Quercion robori-petraeae; S: summa (összeg); Sal: Salicion albae; SCn: ScheuchzerioCaricetea nigrae; Sea: Secalietea; Sio: Sisymbrion officinalis; s. 1.: sensu lato (tágabb értelemben); Spu: Salicetea purpureae; SS: Sedo-Scleranthetea; Str: Salicion triandrae; TA: Tilio platyphyllae-Acerenion pseudoplatani; Ulm: Ulmenion; US: Urtico-Sambucetea.

\section{Irodalomjegyzék}

Becking R. W. 1957: The Zürich-Montpellier Schol of phytosociology. Botanical Review 23: 411-488.

BorHidi A. 1993: A magyar flóra szociális magatartás típusai, természetességi és relatív ökológiai értékszámai. Janus Pannonius Tudományegyetem, Pécs, 95 pp.

BorHidi A. 1995: Social behaviour types, the naturalness and relative ecological indicator values of the higher plants in the Hungarian flora. Acta Botanica Academiae Scientiarum Hungaricae 39: 97-181.

Borhidi A., Kevey B. 1996: An annotated checklist of the Hungarian plant communities II. In: Borhidi A. (ed.) Critical revision of the Hungarian plant communities. Janus Pannonius University, Pécs, pp. 95-138.

Borhidi A., Kevey B., Lendvai G. 2012: Plant communities of Hungary. Akadémiai Kiadó, Budapest, $544 \mathrm{pp}$.

Braun-Blanduet J. 1964: Pflanzensoziologie (ed. 3.). Springer Verlag, Wien-New York, 865 pp.

Horváth F., Dobolyi Z. K., Morschhauser T., Lökös L., Karas L., Szerdahelyi T. 1995: Flóra adatbázis 1.2. Vácrátót, $267 \mathrm{pp}$.

JAKUCS P. 1967: Gedanken zur höheren Systematik der europäischen Laubwälder. Contribuții Botanici Cluj 1967: 159-166.

Kevey B. 1993: A Szigetköz ligeterdeinek összehasonlító-cönológiai vizsgálata. Kandidátusi értekezés (kézirat). Janus Pannonius Tudományegyetem Növénytani Tanszék, Pécs, 108 pp. + 32 fig. +70 tab.

Kevey B. 1998: A Szigetköz erdeinek szukcessziós viszonyai. Kitaibelia 3: 47-63.

Kevey B. 2008: Magyarország erdőtársulásai. Tilia 14: 1-488. + CD-adatbázis (230 táblázat + 244 ábra).

KeVey B. 2016: Puha- és keményfás ligeterdők kapcsolata a Szigetközben. Botanikai Közlemények 103(1): 45-115. http://dx.doi.org/10.17716/BotKozlem.2016.103.1.45

KEVEY B., HirmanN A. 2002: „NS” számítógépes cönológiai programcsomag. In: Aktuális flóraés vegetációkutatások a Kárpát-medencében V. Pécs, 2002. március 8-10. (Összefoglalók), p. 74.

KIRÁLY G. (szerk.) 2009: Új magyar füvészkönyv. Magyarország hajtásos növényei. Határozókulcsok. Aggteleki Nemzeti Park Igazgatóság, Jósvafo, 616 pp.

Moor M. 1958: Die Pflanzengesellschaften schweizerischer Flußauen. Mitteilungen der Schweizerischen Anstalt für das Forstliche Versuchswesen 34: 221-360.

Mucina L., Grabherr G., Wallnöfer S. 1993: Die Pflanzengesellschaften Österreichs III. Wälder und Gebüsche. Gustav Fischer, Jena - Stuttgart - New York, 353 pp. 
MÜLleR Th., GörS S. 1958: Zur Kenntnis einiger Auenwaldgesellschaften im württembergischen Oberland. Beiträge zur naturkundlichen Forschung in Südwestdeutschland 17: 88-165.

Oberdorfer E. 1992: Süddeutsche Pflanzengesellschaften IV. A. Textband. Gustav Fischer Verlag, Jena, Stuttgart, New York, $282 \mathrm{pp}$.

PODANI J. 2001: SYN-TAX 2000 Computer programs for data analysis in ecology and systematics. Scientia, Budapest, 53 pp.

Soó R. 1930: A modern növényföldrajz problémái, irányai és irodalma. A növényszociológia Magyarországon. Magyar Biológiai Kutatóintézet Munkái 3: 1-51.

Soó R. 1964, 1966, 1968, 1970, 1973, 1980: A magyar flóra és vegetáció rendszertani-növényföldrajzi kézikönyve I-VI. Akadémiai kiadó, Budapest.

Elektronikus melléklet: 1-4. táblázatok.

Electronic supplement: Tables 1-4.

1. táblázat. Carduo crispi-populetum albae.

Table 1. Carduo crispi-populetum albae.

2. táblázat. Felvételi adatok az 1. táblázathoz.

Table 2. Relevés data for Table 1.

3. táblázat. Carduo crispi-Populetum nigrae és Senecioni sarracenici-Populetum albae.

Table 3. Carduo crispi-Populetum nigrae and Senecioni sarracenici-Populetum albae.

4. táblázat. Karakterfajok csoportrészesedése.

Table 4. Relative frequencies of character species. 
Kevey B.

\title{
Relationship between black poplar and white poplar riparian forests in the Szigetköz, Hungary
}

\author{
B. KEVEY \\ University of Pécs, Department of Ecology, H-7624 Pécs, Ifjúság útja 6, Hungary; \\ keveyb@gamma.ttk.pte.hu
}

Accepted: 13 June 2016

Key words: black poplar, Hungarian Plain, landscape protection area, syntaxonomy, white poplar.

The syntaxonomical relationship of riparian forests found along the Danube River have been subjected to much debate among phytosociologists. To shed further light on this issue, I conducted a comparative analysis of 65 relevés recorded in white and black poplar riparian forest (Carduo crispi-Populetum nigrae, Senecioni sarracenici-Populetum albae) stands along the Danube in the Szigetköz, NW Hungary. The two communities exhibit apparent differences in physiognomy and the relative proportion of character species, and are grouped separately with multivariate methods. In this analysis, I was able to identify a group of relevés with clearly intermediate characteristics. The existence of intermediate stands supports the notion that the two communities represent successive stages of a successional series, which forms the basis of the latest syntaxonomy of these communities. 